\title{
Application of wheat flour (Triticum aestivum) on spore density and sporulation efficiency of Bacillus megaterium isolated from Litopenaeus vannamei gastrointestinal tract
}

\author{
I MADE DEDI MAHARIAWAN ${ }^{1}$, WAHYU ENDRA KUSUMA ${ }^{2}$, ATING YUNIARTI ${ }^{2}$, M.A.G. BELTRAN ${ }^{3}$, \\ ANIK MARTINAH HARIATI ${ }^{2, \varphi}$ \\ ${ }^{1}$ Graduate Program, Faculty of Fisheries and Marine Sciences, Universitas Brawijaya. Jl. Veteran, Malang 65145, East Java, Indonesia \\ ${ }^{2}$ Department of Aquaculture, Faculty of Fisheries and Marine Science, Universitas Brawijaya. Jl. Veteran, Malang 65145, East Java, Indonesia. \\ Tel./fax.: +62-341-556837, `email: anikmh2021@gmail.com \\ ${ }^{3}$ CVM, Tarlac Agricultural University. Camilang, Tarlac, Philippines
}

Manuscript received: 29 June 2021. Revision accepted: 14 August 2021.

\begin{abstract}
Mahariawan IMD, Kusuma WE, Yuniarti A, Beltran MAG, Hariati AM. 2021. Application of wheat flour (Triticum aestivum) on spore density and sporulation efficiency of Bacillus megaterium isolated from Litopenaeus vannamei gastrointestinal tract. Biodiversitas 22: 3709-3715. Bacillus megaterium is frequently used in fish farming, such as white shrimp (Litopenaeus vannamei) pond, which can produce spores with high stability in its implementation. Currently, spore production still requires the availability of high-cost carbon sources. The objective of this research was to evaluate the effect of different wheat flour doses on spore density and sporulation efficiency of B. megaterium BM1. In flasks, $50 \mathrm{~mL}$ of each test medium was treated with different doses of wheat (10, 20, 30 and $40 \mathrm{~g}$. $\mathrm{L}^{-1}$, respectively) and glucose was used as a control. Each treatment was inoculated with B. megaterium BM1 (2.6 x $10^{8}$ CFU. $\left.\mathrm{mL}^{-1}\right)$ and incubated in a shaker incubator $(120 \mathrm{rpm})$ at $37^{\circ} \mathrm{C}$ for 120 hours. The results showed that the highest vegetative cell concentration $\left(17 \times 10^{8} \mathrm{CFU} . \mathrm{mL}^{-1}\right)$, growth rate $\left(0.8\right.$ hour $\left.^{-1}\right)$ and spore $\left(14.7 \times 10^{8}\right.$ spores. $\left.\mathrm{mL}^{-1}\right)$ were found in the wheat flour dose of $30 \mathrm{~g}$. $\mathrm{L}^{-1}$. Furthermore, the highest sporulation efficiency was achieved at $20 \mathrm{~g}$. $\mathrm{L}^{-1}$ of wheat $(91.30 \%)$ and germination should be done at a dose less than $40 \mathrm{~g}$. $\mathrm{L}^{-1}$. The size of the spores was 1.35-1.39 $\mu \mathrm{m}$. Thus, $30 \mathrm{~g}$. $\mathrm{L}^{-1}$ of wheat flour is a potential dose to produce spore for probiotic candidates.
\end{abstract}

Keywords: Affordable carbon source, Bacillus megaterium, bacterial growth, spore density, sporulation efficiency

\section{INTRODUCTION}

Nowadays, the application of aquaculture biotechnology is one of the efforts to increase fish farming production (Ayoola and Idowu 2008; Danish et al. 2017; Rathore et al. 2019). Probiotics are potential biotechnology products from living microorganisms that are mostly used in the aquaculture industry (Sahu et al. 2008; Verma and Gupta 2015). The advantages of probiotic bacteria in extracellular enzyme secretion (Lee et al. 2012; Eshaghzadeh et al. 2014) and antibacterial compound production (Gozari et al. 2016; Prabhurajeshwar and Chandrakanth 2019; Silva et al. 2020) are important indicators to be continuously developed.

Bacillus is a genus of bacteria that is widely applied as a probiotic in fish and shrimp farming (Buruiana et al. 2014; Swapna et al. 2015; Won et al. 2020). One species of this genus that has been confirmed to have a positive impact on successful aquatic organisms in culture is $B$. megaterium (Li et al. 2009; Aftabuddin et al. 2013). This bacterial species has the ability to sporulate (Grage et al. 2017; Stancu 2020). Some of the benefits in spore as a probiotic candidate are surviving in acid $\mathrm{pH}$ at 2-2.5 (Ananthanarayanan and Dubhashi 2016), heat stability, and storage in dry form (Cutting 2011). From these benefits, bacteria in the form of spores show good stability when applied as probiotics (Bader et al. 2012; Lakshmi et al. 2017).

Production of $B$. megaterium spores involves media composed of various components. One of the media components that presented an important role in initiating the sporulation is the carbon source (Mazmira et al. 2012; Gauvry et al. 2016; Rai and Tewari 2016). Commonly available commercial carbon sources are glucose, lactate (de Vries et al. 2005), and sucrose (Hassan et al. 2014) which provide a high price. The alternative of inexpensive carbon sources that could be used as a substrate to produce spore comes from agro-industrial products (Khardziani et al. 2017a). Wheat flour is an agricultural product that is relatively cheap and easy to find. The utilization of organic carbon from wheat flour is one way to reduce the spore production cost. A previous study underlined that the implementation of carbon sources with inappropriate doses can result in less spore production $\left(<10^{5}\right.$ spores. $\left.\mathrm{mL}^{-1}\right)$ (Senthilkumar et al. 2011). Thus, the use of wheat flour dosage needs to be further evaluated to obtain the optimal dose in producing vegetative cells and spores of $B$. megaterium BM1 isolated from GI tract of white shrimp.

Therefore, this study aimed to evaluate the effect of different wheat flour doses on spore density and sporulation efficiency of B. megaterium BM1. 


\section{MATERIALS AND METHODS}

\section{Preparation of $B$. megaterium BM1 culture}

The isolate of B. megaterium BM1 which isolated from gastrointestinal tract of white shrimp was cultured in Nutrient Agar (NA) with adding sodium chloride 2\% (w/v) at $30^{\circ} \mathrm{C}$ for 24 hours. The re-culture of B. megaterium BM1 isolates was conducted by inoculating the bacterial colonies that have grown on solid media using a loop needle into Nutrient Broth (NB) media. Furthermore, the incubation of the broth culture was in an incubator shaker (120 rpm) at $37^{\circ} \mathrm{C}$ for 18 hours as a stock culture.

\section{Composition of tested media}

The test media in this study consisted of wheat flour, ammonium chloride $\left(\mathrm{NH}_{4} \mathrm{Cl}\right)$ and mineral salts. The doses

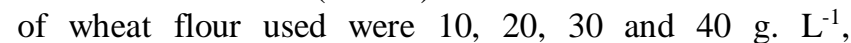
respectively. In contrast, the $\mathrm{NH}_{4} \mathrm{Cl}$ dose added was adjusted to each wheat flour (T. aestivum) dose to obtain a $\mathrm{C}: \mathrm{N}$ ratio of $5: 1$. The composition of the test media that has been determined was dissolved by distilled water and enriched with several minerals such as $\mathrm{CaCO}_{3} 0.3 \mathrm{~g}$. $\mathrm{L}^{-1}$, $\mathrm{MgSO}_{4} .7 \mathrm{H}_{2} \mathrm{O} 0.00033$ g. L $\mathrm{L}^{-1}, \mathrm{MnSO}_{4} \cdot \mathrm{H}_{2} \mathrm{O} 0.12$ g. L $\mathrm{L}^{-1}$, $\mathrm{FeSO}_{4} \cdot 7 \mathrm{H}_{2} \mathrm{O} 0.084$ g. L $\mathrm{L}^{-1}$, and $\mathrm{CaCl}_{2} \cdot 2 \mathrm{H}_{2} \mathrm{O} 0.09$ g. $\mathrm{L}^{-1}$. The control treatment used was glucose as a carbon source with the same $\mathrm{C}: \mathrm{N}$ ratio and minerals as the wheat flour treatment. All of these treatments were repeated 3 times.

\section{Cultivation condition}

Fifty (50) $\mathrm{ml}$ of test media was put into each 100 -mlErlenmeyer flask according to the treatment and sterilized using an autoclave. The stock culture of $B$. megaterium BM1 was inoculated into the test medium as much as $1 \%$ $(\mathrm{v} / \mathrm{v})$. The initial density obtained from the bacterial culture stock was $2.6 \times 10^{8} \mathrm{CFU}$. $\mathrm{mL}^{-1}$. Fermentation of all treatments was carried out in a shaker incubator at a speed of $120 \mathrm{rpm}$ for 24 hours for the vegetative phase and was continued to the sporulation phase for 120 hours.

\section{Counting of vegetative cell, vegetative cell growth rate, spore production, sporulation efficiency and spore germination}

The vegetative cells and spores were counted microscopically with the Neubauer chamber. Shape of the cells became a key to determine distinguish both of them. The vegetative cells are rod-shaped and spores are roundshaped. The special treatment was conducted before counting spores by heating them at $80^{\circ} \mathrm{C}$ for 15 minutes. To assist the calculation of vegetative cells and spores, samples were serially diluted. The measurement of sporulation efficiency was carried out using the highest spore and vegetative data in the predetermined period which referred to the formula from Monteiro et al. (2014). Furthermore, the ability of spores to germinate was done by planting the spore samples onto the germination medium (NB). Spore germination was observed in an incubation time of 24 hours.

\section{Spore visualization on Scanning Electron Microscopy (SEM)}

The highest spores that have been harvested from wheat flour with the optimal dose were visualized by morphology using a Scanning Electron Microscopy (SEM). This shape and size of the spore from the optimal dose of wheat will be compared to the spore that was grown in glucose media. The spore samples were separated between the supernatant and the pellets by centrifugation process at a rate of $1,000 \mathrm{x}$ g using $4^{\circ} \mathrm{C}$ of temperature in 5 minutes. Afterward, the sample was conducted through incubation with $2.5 \%$ of glutaraldehyde in 1.5 hours. The pellets collected from the last stage of centrifugation were followed by gradual dehydration. Visualization of spores was observed in SEM TM 3,000. Spores were measured to determine the size of the spores produced from each treatment.

\section{Statistical analysis test}

The results obtained of whole parameters in this study were tested statistically by one-way ANOVA through SPSS 20 software. The differences of all treatments can be seen from DMRT Test.

\section{RESULTS AND DISCUSSION}

\section{Vegetative cell density and growth rate of $B$. megaterium BM1}

All doses of wheat showed a higher vegetative cell production than the control treatment (glucose) (Figure 1). Even at wheat flour doses of 20,30 , and $40 \mathrm{~g}$. $\mathrm{L}^{-1}$ indicated that the vegetative cell density was two times greater than the control treatment. In this study, the highest of the vegetative cell was obtained at $30 \mathrm{~g} . \mathrm{L}^{-1}$ of wheat flour with a density of $17 \times 10^{8} \mathrm{CFU} . \mathrm{mL}^{-1}$. The growth rate of the vegetative cells of $B$. megaterium BM1 (Figure 2) in all wheat flour concentrations exhibited a higher value than that of the control treatment (glucose). The average growth rate of $B$. megaterium BM1 grown on wheat flour with a dose greater than $10 \mathrm{~g}$. $\mathrm{L}^{-1}$ had a value above 0.75 hour $^{-1}$ and indicated no significant difference ( $p>0.05)$.

Table 1. Vegetative cell densities of germinated B. megaterium BM1 spores (x10 $\left.{ }^{8} \mathrm{CFU} . \mathrm{mL}^{-1}\right)$

\begin{tabular}{cccccc}
\hline $\begin{array}{c}\text { Incubation } \\
\text { (hour) }\end{array}$ & \multicolumn{5}{c}{ Wheat Flour Doses $\left(\mathbf{g}\right.$. L $\mathbf{~}^{\mathbf{1}}$ ) } \\
\cline { 2 - 6 } & $\mathbf{1 0}$ & $\mathbf{2 0}$ & $\mathbf{3 0}$ & $\mathbf{4 0}$ & Control \\
\hline 8 & $3.43 \pm 0.03^{\mathrm{b}}$ & $4.64 \pm 0.04^{\mathrm{c}}$ & $4.67 \pm 0.07^{\mathrm{c}}$ & $2.42 \pm 0.04^{\mathrm{a}}$ & $2.47 \pm 0.02^{\mathrm{a}}$ \\
16 & $7.65 \pm 0.13^{\mathrm{b}}$ & $8.00 \pm 0.20^{\mathrm{b}}$ & $8.93 \pm 0.25^{\mathrm{c}}$ & $6.03 \pm 0.15^{\mathrm{a}}$ & $6.13 \pm 0.21^{\mathrm{a}}$ \\
24 & $9.46 \pm 0.06^{\mathrm{b}}$ & $9.97 \pm 0.21^{\mathrm{c}}$ & $10.13 \pm 0.42^{\mathrm{c}}$ & $8.56 \pm 0.09^{\mathrm{a}}$ & $8.59 \pm 0.23^{\mathrm{a}}$ \\
\hline
\end{tabular}

Note: The different notation between the numbers indicated significant difference $(\mathrm{p}<0.05)$ 


\section{Spore production of $B$. megaterium BM1}

The emergence of spores in this study occurred at 12 hours of incubation for all wheat flour treatments. However, in the control (glucose) treatment, spores first appeared at 18 hours after inoculation (Figure 3). The density of spores continues to increase in line with the decreasing density of vegetative cells. After the initial spores were formed, the number of spores gradually increased up to 84 hours. For all dosages of wheat flour, the highest spore density was reached at hour 84 . In contrast, the control treatment reached peak spore production at hour 96 . Furthermore, the spores indicated the stationary phase until the end of the sporulation time. The highest spore density occurred at a dose of $30 \mathrm{~g}$. L ${ }^{-1}$ of wheat flour with a value of $14.7 \times 10^{8}$ spores. $\mathrm{mL}^{-1}$. This result revealed $233 \%$ greater than that of the control treatment (glucose). The trends as true for the vegetative cells in all wheat flour concentrations.

\section{Sporulation efficiency and spore germination of $\boldsymbol{B}$. megaterium BM1}

In terms of the highest sporulation efficiency, can be seen from Figure 4 that there is no statistical difference in the dosage of wheat flour at 10 and $20 \mathrm{~g} . \mathrm{L}^{-1}$ with a value of more than $90 \%$.

In addition, the spores of $B$. megaterium BM1 that germinated in all treatments increased within 8 hours of the incubation period (Table. 1). The highest vegetative cell density from germination was obtained in the treatment of wheat at a dose of $30 \mathrm{~g}$. $\mathrm{L}^{-1}\left(10.13 \times 10^{8} \mathrm{CFU} . \mathrm{mL}^{-1}\right)$. These results suggested that the spore regrowth from this dose had a value $117 \%$ higher than that of the control treatment (glucose).

\section{Visualization of $B$. megaterium BM1 spores}

Visualization of B. megaterium BM1 spores grown on optimal media (wheat flour at a dose of $30 \mathrm{~g}$. $\mathrm{L}^{-1}$ ) compared to commercial media (glucose) was aimed to determine the morphology and size of the spores obtained. The results revealed that there were no significant differences in the shape in each of the media tested (Figure 5). The results of spore size in this study were grown in wheat flour at a dose of $30 \mathrm{~g}$. $\mathrm{L}^{-1}$ and glucose were $1.35-1.39 \mu \mathrm{m}$ and glucose $1.09-1.47 \mu \mathrm{m})$ respectively.

\section{Discussion}

Microbes require a culture medium consisting of various components to grow, one of them is a carbon source. The results of this study recorded that the implementation of organic carbon sources derived from wheat flour under different doses had a significant effect on the production of vegetative cells. The availability of carbon as nutrition at the appropriate concentration can affect the maximum bacterial growth in the incubation period (Sarudu et al. 2015; Allen and Waclaw 2018). The distinction in time and density achieved by $B$. megaterium BM1 between the wheat flour and control (glucose) treatment was influenced by the different substrate types. Mikkelsen et al. (2009) and Nur et al. (2015) noted that the utilization of different carbon sources in culture media would affect bacterial growth. Moreover, another factor of carbon concentration in different carbon sources also influences vegetative cell growth (Molina-Ramírez et al. 2017). The carbon source available in the environment was absorbed by bacteria cells that function as the substrate of metabolic tissue, then was broken down to supply amino acids and several components that compose the cell (Wang et al. 2019). After reaching the maximum density, the vegetative cells of $B$. megaterium deceased at 12 hours or more. This condition was caused by the availability of nutrients in the culture media gradually decreased. In consequence, the nutrient uptake by vegetative cells would slow down and impacted starvation (Biselli et al. 2020).

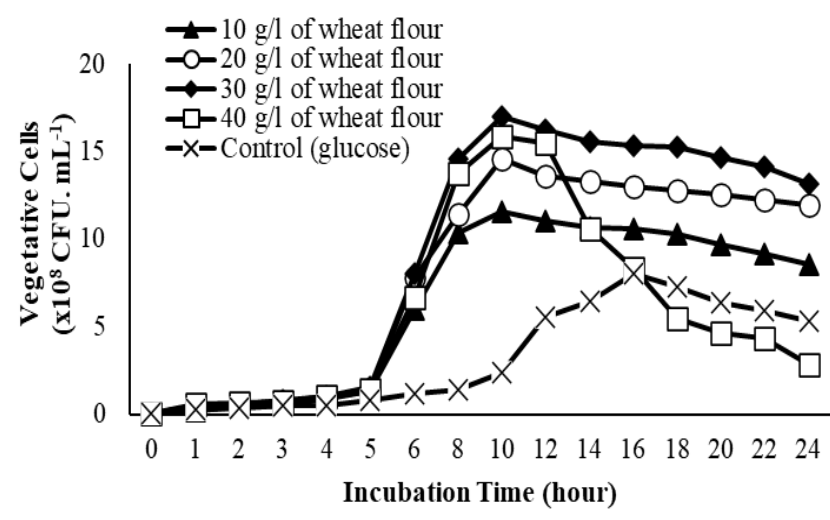

Figure 1. Vegetative cell density of B. megaterium BM1 under different doses of wheat flour

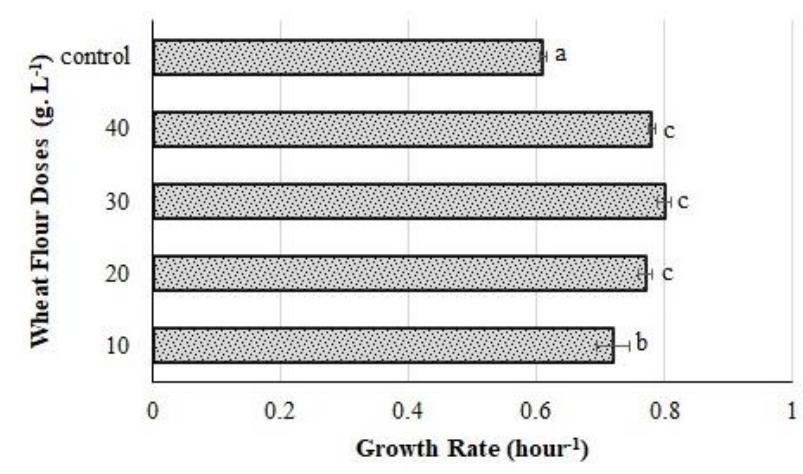

Figure 2. Maximum vegetative cell growth rate of $B$. megaterium BM1 under different doses of wheat flour. Mean data with different alphabets are significantly different at a level of $\mathrm{p}<0.05$ ). 
The maximum growth rate of vegetative cells was directly comparable to the highest density of vegetative cells obtained. The growth rate had different values depending on the growth phase of the bacteria. The bacterial growth rate actually began to decline when the culture conditions entered the stationary phase (Hall et al. 2013). Furthermore, physiologically, there was an increase in the size of B. subtilis cells in line with the growth rate especially in cell length, while the width was constant (Sauls et al. 2019). In this study, the dosage of wheat flour presented an important indicator in influencing the growth rate of vegetative cells. It can be seen that the doses of 30 g. $\mathrm{L}^{-1}$ and $40 \mathrm{~g}$. $\mathrm{L}^{-1}$ of wheat are very close in value. The availability of nutrients in the environment at the right dose could modulate vegetative cells to carry out the macronutrient absorption process in the culture medium. Vadia and Levin (2015) explained that the nutrients available in the culture media would be catabolized by bacteria for biosynthetic process. Metabolites produced through central carbon metabolism could serve as intracellular signals that activated effector proteins in modulating cell cycle development.

The process of vegetative transformation into spores is known as sporulation. The difference in time of spore formation was initiated by nutritional factors in the culture media which began to decline after passing through the stationary phase. The stress condition of vegetative cells formed self-defense against nutrient depletion in the environment. The carbon source of wheat exhibited a higher spore density compared to the control treatment. The utilization of wheat flour in this study showed a good substrate for producing B. megaterium BM1 spores. Other studies that utilize local materials such as molasses and soy flour could produce spores at $5.90 \times 10^{8}$ spores. $\mathrm{mL}^{-1}$ (Salazar-Magallon et al. 2015). Apart from being influenced by the type of carbon sources, the concentration of the carbon sources used as a growth medium also played important role in the expression of the capacity for spore formation in the genus Bacillus (Khardziani et al. 2017b).

Certainly, the concentration of the various carbon sources showed a different number of spores obtained. For instance, the results of this study explained that the highest dosage of wheat flour $(40 \mathrm{~g} / \mathrm{L})$ resulted in a lower spore production of $B$. megaterium BM1 than the doses of $30 \mathrm{~g}$. $\mathrm{L}^{-1}$ and $20 \mathrm{~g}$. $\mathrm{L}^{-1}$. This result was in line with the research by Posada-Uribe et al. (2015) who showed that the use of a carbon dose $\left(2 \mathrm{~g}\right.$. $\left.\mathrm{L}^{-1}\right)$ could produce spores of $5.1 \times 10^{8}$ CFU. $\mathrm{mL}^{-1}$ while at a carbon dose $\left(>11 \mathrm{~g}\right.$. $\left.\mathrm{L}^{-1}\right)$ did not generate spores of B. subtilis. Jackson and Bothast (1990) stated that giving high carbon concentration up to $40.8 \mathrm{~g}$. $\mathrm{L}^{-}$ ${ }^{1}$ inhibited sporulation. According to Kang et al. (1992), at $200 \mathrm{~g}^{-\mathrm{L}^{-1}}$ of carbon, the bacteria unable to generate the spores. In terms of the results of this study, the application

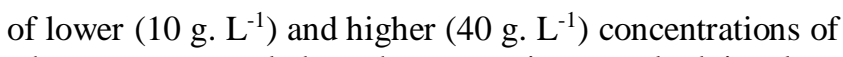
wheat were revealed at the same time resulted in close spore production values. This condition was suspected by the uptake of available nutrients by bacteria at different carbon concentrations. At the lowest carbon dose, it has not been able to provide high vegetative cells density that would be spore candidates. In addition, the administration of the highest carbon dose also impacted the sporulation. The implementation of high glucose levels could inhibit the sporulation by repressing the spoOA gene transcription (Monteiro et al. 2005). The inhibition of the sporulation was known as the pathway of carbon metabolism (Gauvry et al. 2016). Thus, the carbon concentration should be employed in optimal conditions. In consequence, the environment did not experience a shortage or excess carbon source that could prevent the number of spore production.

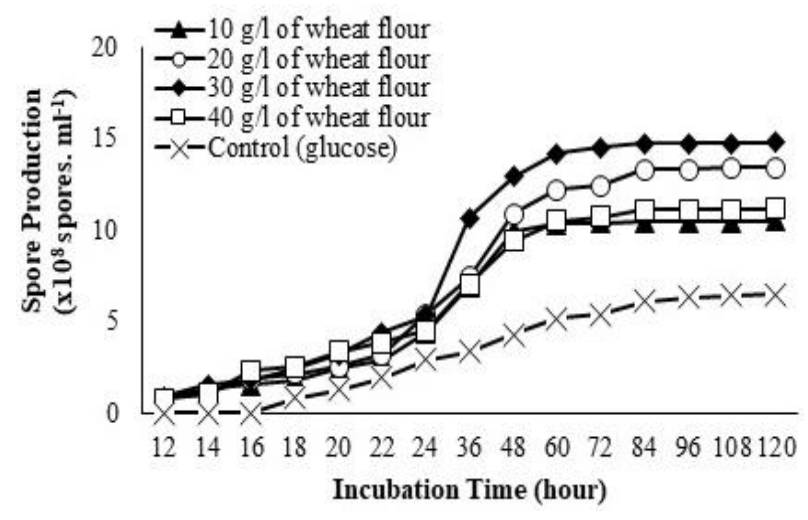

Figure 3. Spore production of $B$. megaterium BM1 under different doses of wheat flour

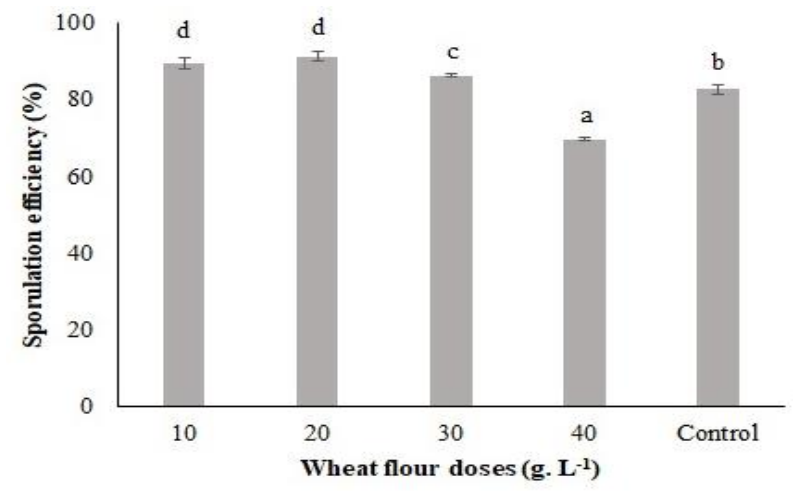

Figure 4. Sporulation efficiency of B. megaterium BM1 under different doses of wheat flour. Mean data with different alphabets are significantly different at a level of $\mathrm{p}<0.05$ ). 


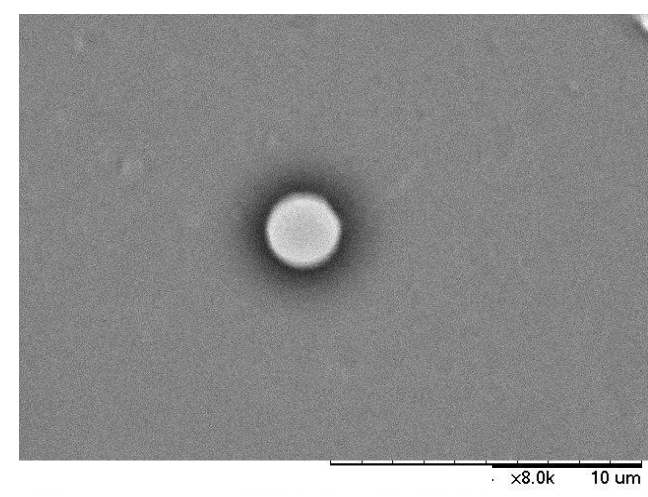

$\mathbf{A}$

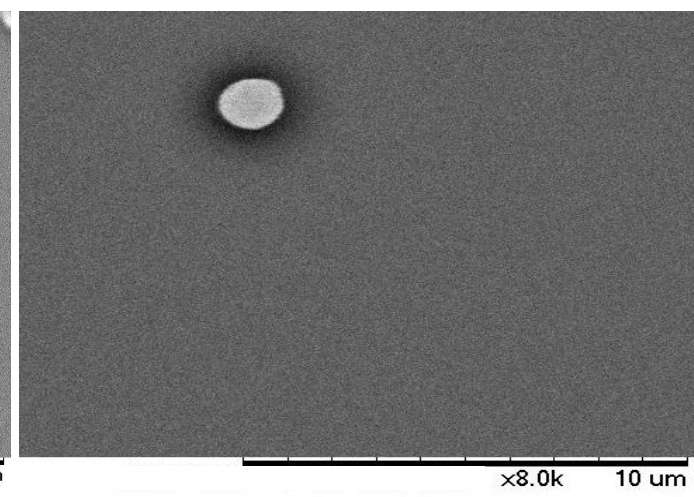

B

Figure 5. Morphological of B. megaterium spores under different carbon sources; A) control (glucose); B) Wheat flour at a dose of $30 \mathrm{~g}$. $\mathrm{L}^{-1}(\mathrm{x} 8,000$ magnification $)$

Sporulation efficiency at doses of flour more than $20 \mathrm{~g}$. $\mathrm{L}^{-1}$ showed a decreasing value. Even the highest dose of wheat $\left(40 \mathrm{~g}\right.$. $\left.\mathrm{L}^{-1}\right)$ showed a lower sporulation efficiency than the control treatment. This condition explained that the high production of vegetative cells and spores was not supported by the high sporulation efficiency obtained. Sporulation efficiency could be achieved with a high percentage when supported by spore availability (Stojanović et al. 2019) and high growth rates (Carvalho et al. 2010). Several factors that influence spore production in increasing efficiency were carbon, nitrogen, and other macronutrients. The carbon and nitrogen sources played an important role in metabolic synthesis by bacteria to initiate sporulation (Anderson and Jayaraman, 2003). The highest sporulation efficiency of B. megaterium BM1 in this study had a value of $15 \%$ greater than the sporulation efficiency of B. subtilis AWS133 grown on DSM media that researched by Serio et al. (2006). In addition, the concentration of carbon sources (glucose) of $0.8-2 \mathrm{~g}^{-\mathrm{L}^{-1}}$ in the culture media resulted in the sporulation efficiency of B. subtilis at 50-90\% (Posada-Uribe et al. 2015). Hence, it could be concluded that the sporulation efficiency really depended on the Bacillus strain used and the nutritional components in the culture media (Roy et al. 2015).

In general, the higher the carbon doses given, the higher the vegetative cell production obtained. On the other hand, in this study, the dose of wheat flour at $30 \mathrm{~g}$. $\mathrm{L}^{-1}$ exhibited a bacterial density higher than at the dose of $40 \mathrm{~g}^{-1} \mathrm{~L}^{-1}$. This condition explained that the high dose of wheat as a carbon source impacted vegetative cells that could not absorb the total of carbon available in culture media optimally. In line with these results, Thomas et al. (2014) also revealed that bacterial growth on excess carbon sources could reduce the survival of $S$. aureus when it entered the stationary phase. Moreover, the availability of excess carbon in bacteria caused metabolic stress which can inhibit bacterial growth (Zhang et al. 2020). Interestingly, excess carbon (glucose) levels not only inhibited the respiration process but also encouraged the transfer of electron to alternate acceptors (Thomas et al. 2014).
The number of spores germinated into vegetative cells showed that wheat flour with a dose of less than $40 \mathrm{~g} . \mathrm{L}^{-1}$ was the best treatment. If the dose of wheat flour given was more than that, it would show lower germination than the control treatment. Germination is a process of returning spores to vegetative cells induced by the availability of new nutrients (carbon, protein, and nucleosides) (Setlow 2003; Krawczyk et al. 2017). Apart from being influenced by nutrient availability, the germination process was also initiated by the presence of non-nutritional factors such as $\mathrm{Ca}^{2+}$-DPA, cationic surfactants, salts, and lysozymes (Setlow 2003). The occurrence of spore germination through releasing of DPA depended on the degradation of the spore cortex layer (Francis and Sorg 2016). Some of the variable conditions that affected sporulation were nutritional composition, temperature, spore preparation method, salt concentration, and oxygen availability (Bressuire-Isoard et al. 2018). Thus, the results showed that the spore quality from different doses of wheat flour at the time of sporulation led to differences in the density of vegetative cells from the germinated spores.

The spore size in this study had a larger size than the size of $B$. subtilis spores $(0.8$ to $1.2 \mu \mathrm{m})$ studied by Ricca and Cutting (2003). The difference in size can be caused by the different Bacillus species used. In addition, the cause of differences in spore size can be tested by sequencing analysis and gene expression of the strains used (Carrera et al. 2007). Although not many studies have shown the effect of differences in spore size and structure on the quality of Bacillus spores, this study showed that lower spore size grown in wheat flour at a dose of $30 \mathrm{~g}^{-1} \mathrm{~L}^{-1}$ resulted in a higher spore count than glucose.

In conclusion, the application of wheat flour can be a potential carbon source to produce B. megaterium BM1 spores with the highest production at the dosage of $30 \mathrm{~g}$. $\mathrm{L}^{-}$ ${ }^{1}$ and sporulation efficiency established less than $40 \mathrm{~g}$. $\mathrm{L}^{-1}$. 


\section{ACKNOWLEDGEMENTS}

This research is supported by the Directorate General of Higher Education, Ministry of Education, Culture, Research, and Technology of the Republic of Indonesia through a PMDSU grant in 2020.

\section{REFERENCES}

Aftabuddin S, Kashem MA, Kader MA, Sikder MNA, Hakim MA. 2013. Use of Streptomyces fradiae and Bacillus megaterium as probiotics in the experimental culture of tiger shrimp Penaeus monodon (Crustacea, Penaeidae). Aquac Aquarium Conserv Legislation 6: 253267

Allen RJ, Waclaw B. 2018. Bacterial growth: a statistical physicist's guide. Rep Prog Phys 82: 1-55.

Ananthanarayanan L, Dubhashi A. 2016. Study of probiotic attributes of two isolates Bacillus aerius and Bacillus cereus. Int J Res Stud Biosci 4: 34-39.

Anderson RKI, Jayaraman K. 2003. Influence of carbon and nitrogen sources on the growth and sporulation of Bacillus thuringiensis var Galleriae for biopesticide production. Chem Biochem Eng Q 17: $225-$ 231

Ayoola SO, Idowu AA. 2008. Biotechnology and species development in aquaculture. Afr J Biotechnol 7: 4722-4725

Bader J, Albin A, Stahl U. 2012. Spore-forming bacteria and their utilisation as probiotics. Beneficial Microb 3: 67-75. DOI 10.3920/BM2011.0039

Biselli E, Schink SJ, Gerland U. 2020. Slower growth of Escherichia col leads to longer survival in carbon starvation due to a decrease in the maintenance rate. Mol Syst Biol 16: e9478.

Bressuire-Isoard C, Broussolle V, Carlin F. 2018. Sporulation environment influences spore properties in Bacillus: Evidence and insights on underlying molecular and physiological mechanisms. FEMS Microbiol Rev 42: 614-626. DOI: 10.1093/femsre/fuy021

Buruiana CT, Profir AG, Vizireanu C. 2014. Effects of probiotic Bacillus species in aquaculture - An overview. Ann Univ Dunarea de Jos Galati Fascicle VI: Food Technol 38: 9-17.

Carrera M, Zandomeni RO, Fitzgibbon J, Sagripanti JL. 2007. Difference between the spore sizes of Bacillus anthracis and other Bacillus species. J Appl Microbiol 102: 303-312. DOI: 10.1111/j.13652672.2006.03111.x

Carvalho ALUD, Oliveira FHPCD, Mariano RDLR, Gouveia ER, SoutoMaior AM. 2010. Growth, sporulation and production of bioactive compounds by Bacillus subtilis R14. Braz Arch Biol Technol 53: 643-652. DOI: 10.1590/S1516-89132010000300020

Cutting SM. 2011. Bacillus probiotics. Food Microbiolol= 28: 214-220. DOI: 10.1016/j.fm.2010.03.007

Danish M, Trivedi RN, Kanyal P, Khati A, Agrawal R. 2017. Importance of biotechnology in fish farming system : an overview. Progr Res Int J 12: 7-14.

de Vries YP, Atmadja RD, Hornstra LM, de Vos WM, Abee T. 2005 Influence of glutamate on growth, sporulation, and spore properties of Bacillus cereus ATCC 14579 in defined medium. Appl Environ Microbiol 71: 3248-3254. DOI: 10.1128/AEM.71.6.3248-3254.2005

Eshaghzadeh H, Hoseinifar SH, Vahabzadeh H, Ringo E. 2014. The effects of dietary inulin on growth performances, survival and digestive enzyme activities of common carp (Cyprinus carpio) fry. Aquac Nutr 21: 242-247. DOI: 10.1111/anu.12155

Francis MB, Sorg JA. 2016. Dipicolinic Acid release by germinating clostridium difficile spores occurs through a mechanosensing mechanism. mSphere 1: 1-13.

Gauvry E, Mathot AG, Leguérinel I, Couvert O, Postollec F, Broussolle V, Coroller L. 2016. Knowledge of the physiology of spore-forming bacteria can explain the origin of spores in the food environment. Res Microbiol 168: 369-378. DOI: 10.1016/j.resmic.2016.10.006

Gozari M, Mortazavi MS, Bahador N, Rabbaniha M. 2016. Isolation and screening of antibacterial and enzyme producing marine actinobacteria to approach probiotics against some pathogenic vibrios in shrimp Litopenaeus vannamei. Iran J Fish Sci 15: 630-644.

Grage K, McDermott P, Rehm BHA. 2017. Engineering Bacillus megaterium for production of functional intracellular materials. Microb Cell Factories 16: 1-12. DOI: 10.1186/s12934-0170823-5

Hall BG, Acar H, Nandipati A, Barlow M. 2013. Growth rates made easy. Mol Biol Evol 31: 232-238. DOI: 10.1093/molbev/mst187

Hassan SS, Malek RA, Atim A, Jikan SS, Fuzi SFZM. 2014. Effects of different carbon sources for high level lactic acid production by Lactobacillus casei. Appl Mech Mater 695: 220-223. DOI: 10.4028/www.scientific.net/AMM.695.220

Jackson MA, Bothast RJ. 1990. Carbon concentration and carbon-tonitrogen ratio influence submerged-culture conidiation by the potential bioherbicide Colletotrichum truncatum NRRL 13737. Appl Environ Microbiol 56: 3435-3438. DO: 10.1128/aem.56.11.34353438.1990

Kang BC, Lee SY, Chang HN. 1992. Enhanced spore production of Bacillus thuringiensis by fed-batch culture. Biotechnol Lett 14: 721726. DOI: $10.1007 / \mathrm{BF} 01021650$

Khardziani T, Kachlishvili E, Sokhadze K, Elisashvili V, Weeks R, Chikindas ML, Chistyakov V. 2017a. Elucidation of Bacillus subtilis KATMIRA 1933 potential for spore production in submerged fermentation of plant raw materials. Probiotics Antimicrob Proteins 9: 435-443.

Khardziani T, Sokhadze K, Kachlishvili E, Chistyakov V, Elisashvili V. 2017b. Optimization of enhanced probiotic spores production in submerged cultivation of Bacillus amyloliquefaciens B-1895. J Microbiol Biotechnol Food Sci 7: 132-136.

Krawczyk AO, Jong AD, Omony J, Holsappel S, Wells-Bennik MHJ, Kuipers OP, Eijlander RT. 2017. Spore heat activation requirements and germination responses correlate with sequences of germinant receptors and with the presence of a specific spoVA2mob operon in foodborne strains of Bacillus subtilis. Appl Environ Microbiol 83: 116. DOI: 10.1128/AEM.03122-16

Lakshmi SG, Jayanthi N, Saravanan M, Ratna MS. 2017. Safety assesment of Bacillus clausii UBBC07, a spore forming probiotic. Toxicol Rep 4: 62-71. DOI: 10.1016/j.toxrep.2016.12.004

Lee J, Park I, Choi Y, Cho J. 2012. Bacillus strains as feed additives: In vitro evaluation of its potential probiotic properties. Revista Colombiana de Ciencias Pecuaris 25: 577-585

Li J, Tan B, Mai K. 2009. Dietary probiotic Bacillus OJ and isomaltooligosaccharides influence the intestine microbial populations, immune responses and resistance to white spot syndrome virus in shrimp (Litopenaeus vannamei). Aquaculture 291: 35-40

Mazmira MM, Ramlah SAA, Rosfarizan M, Ling TC, Ariff AB. 2012. Effect of saccharides on growth, sporulation rate and $\delta$-endotoxin synthesis of Bacillus thuringiensis. Afr J Biotechnol 11: 9654-9663. DOI: $10.5897 / \mathrm{AJB} 11.1391$

Mikkelsen D, Flanagan BM, Dykes GA, Gidley MJ. 2009. Influence of different carbon sources on bacterial cellulose production by Gluconacetobacter xylinus strain ATCC 53524. J Appl Microbiol 107: 576-583. DOI: 10.1111/j.1365-2672.2009.04226.X

Molina-Ramirez C, Castro M, Osorio M, Torres-Taborda M, Gomez B, Zuluaga R, Gomez C, Ganan P, Rojas OJ, Castro C. 2017. Effect of different carbon sources on bacterial nanocellulose production and structure using the low $\mathrm{pH}$ resistant strain Komagataeibacter medellinensis. Matererials 10: 639.

Monteiro SMS, Clemente JJ, Carrondo T, Cunha AE. 2014. Enhanced spore production of Bacillus subtillis grow in a chemically defined medium. Adv Microbiol 4: 444-454. DOI: 10.4236/aim.2014.48049

Monteiro SM, Clemente JJ, Henriques AO, Gomes RJ, Carrondo MJ, Cunha AE. 2005. A procedure for high-yield spore production by Bacillus subtilis. Biotechnol Progr 21: 1026-1031. DOI: 10.1021/bp050062z

Nur IT, Tahera J, Munna MS, Rahman MM, Noor R. 2015. Impact of different carbon sources on the in vitro growth and viability of Escherichia coli (SUBE01) and Salmonella spp. (SUBS01) cells. Bangladesh J Microbiol 32: 39-44

Posada-Uribe LF, Romero-Tabarez M, Villegas-Escobar V. 2015. Effect of medium components and culture conditions in Bacillus subtilis EA-CB0575 spore production. Bioprocess Biosyst Eng 38: 18791888. DOI: $10.1007 / \mathrm{s} 00449-015-1428-1$

Prabhurajeshwar C, Chandrakanth K. 2019. Evaluation of antimicrobial properties and their substances against pathogenic bacteria in-vitro by probiotic Lactobacilli strains isolated from commercial yoghurt. Clin Nutr Exp 23: 97-115. DOI: 10.1016/j.yclnex.2018.10.001

Rai D, Tewari AK. 2016. Evaluation of different carbon and nitrogen sources for better growth and sporulation of T. harzianum (Th14). J 
Agric Biotechnol Sustain Dev 8: 67-70. DOI 10.5897/JABSD2016.0262

Rathore SS, Mamun MAA, Nasren S, Rakesh K. 2019. Biotechnology: To speedup aquaculture. J Entomol Zool Stud 7: 706-708.

Ricca E, Cutting SM. 2003. Emerging applications of bacterial spores in nanobiotechnology. J Nanobiotechnol 1: 1-10. DOI: 10.1186/14773155-1-6

Roy SV, Hajare SN, Gautam S, Deobagkar D, Sharma A. 2015 Sporulation-associated mother cell lysis in Bacillus displays markers of programmed cell death. Curr Sci 109: 1283-1292. DOI $10.18520 / \mathrm{cs} / \mathrm{v} 109 / \mathrm{i} 7 / 1283-1292$

Sahu MK, Swarnakumar NS, Sivakumar K, Thangaradjou T, Kannan L. 2008. Probiotics in aquaculture: importance and future perspectives. Indian J Microbiol 48: 299-308. DOI: 10.1007/s12088008-0024-3

Salazar-Magallon JA, Hernandez-Velazquez VM, Alvear-Garcia A Arenas-Sosa I, Pena-Chora G. 2015. Evaluation of industrial byproducts for the production of Bacillus thuringiensis strain GP139 and the pathogenicity when applied to Bemisia tabaci nymphs. Bull Insectol 68: 103-109.

Sarudu NH, Selaman OS, Baini R, Rosli NA. 2015. Evaluation on factors affecting bacteria growth in collected rainwater. J Civil Eng Sci Technol 6: 11-17. DOI: 10.33736/jcest.146.2015

Sauls JT, Cox SE, Do Q, Castillo V, Ghulam-Jelani Z, Jun S. 2019. Grampositive and Gram-negative bacteria share common principles to coordinate growth and the cell cycle at the single-cell level. bioRxiv 726596.

Senthilkumar M, Nizam M, Narayanasamy P. 2011. Development of a semi-synthetic medium for production of azygospores of Zoophthora radicans (Brefeld) Batko, a pathogen of rice leaf folder. J Biopecticides 4: 43-47.

Serio AW, Pechter KB, Sonenshein AL. 2006. Bacillus subtilis aconitase is required for efficient late-sporulation gene expression. J Bacteriol 188: 6396-6405. DOI: 10.1128/JB.00249-06

Setlow P. 2003. Spore germination. Curr Opin Microbiol 6: 550-556. DOI: $10.1016 /$ j.mib.2003.10.001
Silva DR, Sardi JDCO, Pitangui NDS, Roque SM, Silva ACBD, Rosalen PL. 2020. Probiotics as an alternative antimicrobial therapy: Current reality and future directions. J Funct Foods 73: 104080.

Stancu MM. 2020. Biosurfactant production by a Bacillus megaterium strain. Open Life Sci 15: 629-637. DOI: 10.1515/biol-2020-0068

Stojanovic SS, Karabegovic I, Beskoski V, Nikolić N, Lazić M. 2019. Bacillus based microbial formulations: Optimization of the production process. Hemijska Industrija 73: 169-182. DOI: 10.2298/HEMIND190214014S

Swapna B, Venkatrayulu C, Swathi AV. 2015. Effect of probiotic bacteria Bacillus licheniformis and Lactobacillus rhamnosus on growth of the Pacific white shrimp Litopenaeus vannamei (Boone, 1931). Eur J Exp Biol 5: 31-36.

Thomas VC, Sadykov MR, Chaudhari SS, Jones J, Endres JL, Widhelm TJ, Ahn JS, Jawa RS, Zimmerman MC, Bayles KW. 2014. A central role for carbon-overflow pathways in the modulation of bacterial cell death. PLOS Pathogens 10: 1-13. DOI: 10.1371/journal.ppat.1004205

Vadia S, Levin PA. 2015. Growth rate and cell size: a re-examination of the growth law. Curr Opin Microbiol 24: 96-103. DOI: 10.1016/j.mib.2015.01.011

Verma G, Gupta A. 2015. Probiotics application in aquaculture: Improving nutrition and heath. J Anim Feed Sci Technol 3: 53-64.

Wang X, Xia K, Yang X, Tang C. 2019. Growth strategy of microbes on mixed carbon sources. Nat Commun 10: 1-7. DOI: 10.1038/s41467019-09261-3

Won S, Hamidoghli A, Choi W, Bae J, Jang WJ, Lee S, Bai SC. 2020. Evaluation of potential probiotics Bacillus subtilis WB60, Pediococcus pentosaceus, and Lactococcus lactis on growth performance, immune response, gut histology and immune-related genes in Whiteleg Shrimp, Litopenaeus vannamei. Microorganisms 8: 1-15. DOI: 10.3390/microorganisms8020281

Zhang H, Lyu Z, Fan Y, Evans CR, Barber KW, Banerjee K, Igoshin OA, Rinehart J, Ling J. 2020. Metabolic stress promotes stop-codon readthrough and phenotypic heterogeneity. Proc Natl Acad Sci United States of America 117: 22167-22172 